\title{
Crop water productivity and economic evaluation of drip-irrigated soybeans (Glyxine max L. Merr.)
}

Omotayo B Adeboye ${ }^{1 *}$, Bart Schultz ${ }^{2}$, Kenneth $\bigcirc$ Adekalu and Krishna Prasad ${ }^{2}$

\begin{abstract}
Background: Effective management of water under irrigated agriculture is crucial to ensure food security. One crop that has high irrigation economic potential at local and international scales is soybean. This article presents the outcome of field experiments conducted in the dry seasons of 2013 and 2014 in Nigeria on the effects of deficit irrigation (DI) practices on reproductive stages of soybean. The experimental factor was the timing of irrigation. The five treatments were full irrigation (FI); skipping of irrigation every other week during flowering; pod initiation; seed filling and maturity stages.The crop was planted in a randomized complete block design with three replicates and inline drip irrigation was used to apply water. Leaf area index, dry above-ground biomass and seed yield were measured and the soil water balance approach was used to determine seasonal crop water use.

Results: Seasonal crop water use for the treatment in which deficit irrigation was imposed at seed filling stage was $364 \mathrm{~mm}$ while for the control treatment with full irrigation, seasonal crop water use was $532 \mathrm{~mm}$. The seed yield reduced by 18.8 and $21.9 \%$ when DI was imposed during flowering and pod initiation, respectively. Similarly, the seed yield reduced by 24.4 and $47.9 \%$ when DI was imposed during maturity and seed filling. Water productivity (WP) reduced by 6.8 and $12.4 \%$ when DI was used during flowering and pod initiation, respectively. However, WP reduced by 20 and $35 \%$ during maturity and seed filling. DI during reproductive stages reduced economic water productivity by $6.7-35 \%$ while revenue was reduced by $18.5-47.7 \%$.

Conclusions: Full irrigation should be practiced to maximize water productivity. Weekly skipping of irrigation during seed filling will substantially reduce the seed yield and water productivity while skipping during flowering may be a viable option when water is scarce and land is not limiting. Economic evaluation will guide policy makers at basin scales for formulating improved and efficient water management plans under all varying weather conditions. DI can be used to optimise water productivity. The results will be beneficial in adopting deficit irrigation in a manner that will improve economic water productivity.
\end{abstract}

Keywords: Soybean, Deficit irrigation, Dry above-ground biomass, Water productivity, Irrigation water productivity, Harvest index, Nigeria

\section{Background}

The need for reduction in water use by agriculture is being advocated globally due to stiffer competition among fresh water users such as industry and the environment. Several suggestions have been made to

\footnotetext{
*Correspondence: adeboyeomotayo@yahoo.com

${ }^{1}$ Department of Agricultural and Environmental Engineering, Obafemi

Awolowo University, Ile-lfe, Nigeria

Full list of author information is available at the end of the article
}

optimize the use of water for crop production. One of them is that water should be applied to crops when they need it most, that is when shortage of water could lead to significant reduction in yield. This approach is called regulated, pre-planned or deficit irrigation (DI) [1]. DI is a means of reducing crop water use while minimizing adverse effects on crop yield [2-4]. In order to adopt DI, information on the responses of crops to water deficit at various stages is required. 
Articles have been published on the possibility of saving irrigation water without significant reduction in the yield through DI. Available data show that an equivalent or greater yield can be obtained by delaying irrigation until soybeans are in the reproductive stage of growth as compared with (FI) full irrigation [5]. Stegman et al. [6] stated that a short period of water stress during flowering may lead to a drop in flowers and pods at the lower canopy but this will be compensated by increased pod set at the upper node when irrigation resumes later in the crop life. Stegman et al. [6] concluded that water stress in the full pod to seed fill stage was most detrimental to yield in soybeans. A parameter for assessing the effect of DI on crop yield is called the crop response factor $\left(k_{y}\right)$. It is the measure of sensitivity of a crop to DI [7]. Crop response factors vary from one crop to the other, cultivar, stage of growth, duration of DI, irrigation method and management. A value of $\mathrm{k}_{\mathrm{y}}$ greater than 1 indicates that the expected relative decrease in yield for a given evapotranspiration deficit is proportionally greater than the evapotranspiration deficit [3]. The level of accuracy of the crop response factor depends on range and data for yield and evapotranspiration and assumes a linear relationship of the data. Research on identifying the critical stage where water stress can reduce yield and performance of soybean is still in progress. Bustomi Rosadi et al. [8] investigated the effects of water stress during the vegetative stage of soybeans. They found that the optimal water management of soybean with the highest yield efficiency occurred when the water stress coefficient was 0.80 for the vegetative phase.

Water stress during the reproductive stage has also been found to influence the number and seeds per pod [9]. Water stress at the late reproductive stage accelerated senescence, reduced the seed filling period and pod sizes [10]. Korte et al. [11] concluded after comparing three irrigations on eight cultivars of soybean that a single irrigation during pod elongation was the most beneficial to soybeans because it increases seeds per plant and irrigation at seed enlargement increases seed weight. Irrigation of soybeans at any stage did not significantly increase yield or only slightly increased the yield above that of non-irrigated treatment if the rainfall is sufficient to supply the water requirement [12]. Karam et al. [13] investigated the effects of DI at full flowering (R2) stage of soybeans. They reported that DI reduced above-ground biomass and seed yield by 16 and 4\%, respectively, and that DI at seed filling at the beginning of seed formation (R5) stage reduced these two parameters by 6 and $28 \%$, respectively. However, they did not investigate economic implications of DI on soybean. Torrion et al. [14] examined the effects of DI on eight soybean cultivars. They reported that a season-long deficit irrigation strategy significantly reduced the seed yield but they did not evaluate the economic effects of DI. Sincik et al. [15] investigated the effects of DI on soybeans. They reported that non-irrigated and all deficit irrigation treatments significantly reduced biomass and seed yield and that leaf area indices were significantly reduced at all growth stages. However, they also did not evaluate the economic implications of DI on the crop.

Garcia et al. [16] investigated the effects of DI regimes on yield and water productivity of different genotypes of soybean. The results showed that DI significantly reduced dry matter, canopy height, and maximum leaf area index. They reported that seed yield increased at a rate of $7.20 \mathrm{~kg}$ for every mm of total seasonal water use and that irrigation water productivity (IWP) significantly differed among different genotypes, a feature which can be used as a criterion for achieving greater yields in supplemental irrigation. Gercek et al. [17] obtained the highest seed yield of soybeans at full irrigation. The highest values of water productivity (WP) and IWP were obtained when 75 and $50 \%$ of the full crop water use was applied, while lower total yield was obtained when $50 \%$ of the water use was applied.

Water productivity of soybean can be increased by eliminating irrigation at the vegetative stage when evapotranspiration is predominantly by water evaporation from the soil [17]. Reduction in the yield varies from one place to the other where DI is practiced. Environmental and soil factors determine the level of soil water evaporation and availability of water in the soil for plant use. Therefore, there is a need to carry out a comprehensive assessment on the impact of DI on the yield of crops before implementing it as a policy program. This assessment will be used in convincing farmers and other stakeholders on the benefits that may be derived from such approaches.

If drip irrigation is managed properly, it could optimise water use for crop production in addition to other benefits. The objectives of this study were to determine the effects of DI at reproductive stages, by applying a drip irrigation system, on yield components, water productivity (WP), irrigation water productivity (IWP), economic water productivity, and economic returns of soybeans in Ile-Ife, Nigeria. It is located in Ogun-Osun River Basin, southwest of Nigeria.

\section{Methods}

\section{Study area}

The study was carried out during the dry seasons of 2013 and 2013/2014 at the teaching and research farms of Obafemi Awolowo University, Ile-Ife, Nigeria. Ile-Ife town is located at latitude $7^{\circ} 28^{\prime} 0^{\prime \prime} \mathrm{N}$ and longitude $4^{\circ} 34^{\prime} 0^{\prime \prime} \mathrm{E}$, $271 \mathrm{~m}$ above mean sea level. It is in the sub-humid area of 
Nigeria. The dry seasons extend from November to March, and the climate is conducive for the cultivation of grains and legumes under total and supplementary irrigation. In the recent times, there is variability in monthly distribution of rainfall in terms of depth, time of occurrence and areal distribution. These fluctuations in the daily rainfall often make it risky to grow crops during the rainy seasons or difficult to make a precise prediction of rainfall contributions to crop water use during dry seasons.

Data on temperature, relative humidity, global solar radiation, and rainfall for both seasons are shown in Table 1. The first season was warmer than the second was. The upper $50 \mathrm{~cm}$ was sandy loam while the lower $50 \mathrm{~cm}$ contained more clay. The upper $50 \mathrm{~cm}$ was richer in organic matter than the lower $50 \mathrm{~cm}$. The $\mathrm{pH}$, phosphorus and iron were higher in the upper $50 \mathrm{~cm}$ than the lower $50 \mathrm{~cm}$ of the soil profile. However, the average total nitrogen, sodium and potassium in the upper and lower $50 \mathrm{~cm}$ of the soil profile were uniform.

\section{Experimental treatments}

The experimental treatments and their descriptions are shown in Table 2.

\section{Agronomic practice}

The experimental field was harrowed at the beginning of the fieldwork in both seasons. Force up ${ }^{\mathrm{TM}}$ was applied at a rate of $3 \mathrm{~L} \mathrm{ha}^{-1}$ on the prepared land to control Heteropogon contortus (L.). The experiment was laid out in a randomized complete block design with three replicates. Due to the dryness of the soil shortly before planting, the field was pre-wetted to a depth of $20 \mathrm{~mm}$ in order to initiate seed germination. The cultivar TGX $14482^{\mathrm{E}}$, an indeterminate variety, was planted on February 2, 2013 (first season) and November 8, 2013 (second season). In the first season, delay in the procurement of irrigation equipment coupled with logistic challenges was responsible for the commencement of the experiment in the stated time. Three seeds were sown on flat land at a depth of $4 \mathrm{~cm}$ with plant spacing 0.6 by $0.3 \mathrm{~m}$, which produced 55,556 plants $\mathrm{ha}^{-1}$. Each plot contained 68 plants $\left(12 \mathrm{~m}^{2}\right)$ arranged in four rows that is, 17 plants per row. Seedlings were thinned to one plant per stand after full establishment. An alleyway of $1 \mathrm{~m}$ was used in separating the plots from each other to allow for easy movement. The area of the field was $19 \mathrm{~m}$ by $15 \mathrm{~m}\left(285 \mathrm{~m}^{2}\right)$. At the borders of the field, trenches $(0.3 \mathrm{~m}$ by $0.4 \mathrm{~m})$ were constructed to

Table 1 Meteorological data at the weather station in the two seasons (standard deviations in parentheses)

\begin{tabular}{|c|c|c|c|c|c|c|c|c|c|}
\hline \multirow[t]{2}{*}{ Year/month } & \multicolumn{3}{|c|}{ Temperature $\left({ }^{\circ} \mathrm{C}\right)$} & \multicolumn{3}{|c|}{ Relative humidity (\%) } & \multicolumn{2}{|c|}{ Global solar radiation $\left(\mathrm{Wm}^{-2}\right)$} & \multirow{2}{*}{$\begin{array}{l}\text { Rainfall }(\mathrm{mm}) \\
\text { Mean }\end{array}$} \\
\hline & Max & Min & Mean & Max & Min & Mean & Max & Mean & \\
\hline \multicolumn{10}{|l|}{2013} \\
\hline Feb & 41.0 & 18.0 & $27.5(3.7)$ & 94.3 & 10.1 & $66.0(18.6)$ & 904 & $161(234)$ & 55.3 \\
\hline Mar & 34.5 & 21.3 & $27.2(3.4)$ & 94.4 & 42.4 & $76.4(14.0)$ & 810 & $128(219)$ & 32.3 \\
\hline Apr & 34.8 & 21.7 & $25.8(3.7)$ & 94.5 & 40.4 & $78.5(13.7)$ & 1,003 & $190(266)$ & 44.9 \\
\hline May & 37.0 & 20.8 & $26.1(2.7)$ & 95.6 & 15.6 & $81.5(12.9)$ & 985 & $181(245)$ & 129 \\
\hline \multicolumn{10}{|l|}{$2013 / 2014$} \\
\hline Nov & 33.5 & 20.5 & $26.3(2.8)$ & 100 & 37.9 & $87.2(22.3)$ & 959 & $180(265)$ & - \\
\hline Dec & 33.1 & 16.7 & $25.9(3.3)$ & 100 & 20.3 & $78.6(23.5)$ & 837 & $179(250)$ & 50 \\
\hline Jan & 35.4 & 18.1 & $26.4(3.2)$ & 100 & 15.1 & $81.3(25.2)$ & 841 & 152 (219) & - \\
\hline Feb & 36.3 & 19.7 & $27.5(3.7)$ & 100 & 13.5 & $68.8(25.4)$ & 798 & 166 (229) & - \\
\hline
\end{tabular}

Table 2 Irrigation treatments in the two seasons

\begin{tabular}{ll}
\hline Treatment & Description \\
\hline $\mathrm{TT}_{1111}$ & $\begin{array}{r}\text { Irrigation was maintained weekly during all growth stages: flowering (beginning and full bloom), pod initiation (beginning and full pod), } \\
\text { seed filling (beginning and full seed) and (beginning and full maturity) maturity stage (reference treatment) }\end{array}$ \\
$\mathrm{TT}_{0111}$ & Irrigation was skipped every other week during flowering only \\
$\mathrm{TT}_{1011}$ & Irrigation was skipped every other week during pod initiation only \\
$\mathrm{TT}_{1101}$ & Irrigation was skipped every other week during seed filling only \\
$\mathrm{TT}_{1110}$ & Irrigation was skipped every other week during maturity only \\
\hline
\end{tabular}


divert rainwater away from the plots. The inline polyvinyl chloride (PVC) drip pipes ( $3 / 4^{\prime \prime}$ Blank Tube) pre-spaced at $0.3 \mathrm{~m}$ intervals were arranged in rows and locked $\left(3 / 4^{\prime \prime}\right.$ EZ lock coupler) at the downstream end of each row to prevent leakage of water. Water locks ( $3 / 4^{\prime \prime}$ EZ lock coupler) were placed at the upstream ends of drip pipes to control the application of water. Water was pumped using a gasoline engine $(6.5 \mathrm{hp})$ from a distant stream into an overhead 2,500 L plastic tank (8 $\mathrm{m}$ high) and connected through a pipe $\left(1 / 2^{\prime \prime}\right.$ blank tube) via a water filter (Dripworks, Inc., CA, USA) to the drip lines (rows) in the plots. Water flowed from the overhead tank into the drip lines by gravity.

Insects and beetles were controlled by using Magic Force $^{\text {TM }}$ (Jubaili Agro Chemicals) at a rate of $1.5 \mathrm{~L} \mathrm{ha}^{-1}$ regularly. The single coefficient approach was used to estimate daily crop water use [18]. After maturity on May 25, 2013 (112 days after planting (DAP)) and February 25, 2014 (110 DAP), an area of $5.37 \mathrm{~m}^{2}$ in the central rows was harvested from each of the plots and the seed yields per ha were estimated.

\section{Dry biomass (DBM)}

At intervals of 7 days from 14 DAP in both seasons, the above-ground biomasses were measured from an area of $0.358 \mathrm{~m}^{2}$ in each plot from two replicates. The aboveground biomass was oven-dried at a temperature of $70^{\circ} \mathrm{C}$ for $48 \mathrm{~h}$ until constant weight and the DBM per unit area was estimated. Harvest Index (HI) was determined from the ratio of the mass of the seed yield to that of oven dry biomass [19].

\section{Water application}

\section{Design of the drip irrigation system}

A pressure-compensating inline drip line (Dripworks, Inc., CA, USA) with emitter capacity of $2.2 \mathrm{~L} \mathrm{~h}^{-1}$ with operating pressure of $100 \mathrm{kPa}$ was used. Each lateral was $5 \mathrm{~m}$ long and contained 17 point inline emitters pre-spaced at intervals of $0.3 \mathrm{~m}$. The volume of water required per plant per day was determined from the ratio of the product of peak evapotranspiration and wetted area occupied by each plant to the emission uniformity. Irrigation frequency was determined from the ratio of the readily available moisture to the peak crop water use. The average amounts of water applied during initial, mid and late stages were 1.13, 6.69 and $3.83 \mathrm{~mm}$ day $^{-1}$, respectively.

\section{Measurement of soil moisture}

The experimental field was characterised by sandy loam soil. The water holding capacity of the soil was $110 \mathrm{~mm} \mathrm{~m}^{-1}$. The field capacity and permanent wilting point were 0.248 and $0.138 \mathrm{~m}^{3} \mathrm{~m}^{-3}$, respectively. Soil moisture contents were measured from two replicates of each treatment using the gravimetric method at intervals of $0.10 \mathrm{~m}$ from 0 to $0.60 \mathrm{~m}$. Wet soil samples were collected using a $53 \mathrm{~mm}$ diameter steel core sampler. The samples were weighed immediately in the field, kept in a sealed polythene bag and transported to the laboratory where they were oven-dried at $105^{\circ} \mathrm{C}$ for about $48 \mathrm{~h}$ until constant weight. The volumetric water content was determined by multiplying soil moisture measurement (\%) by bulk density of each layer. The volumetric soil moisture was converted to linear depth $(\mathrm{mm})$ of water by multiplying it with the depth of each layer [20]. Soil around the roots was carefully removed, the roots were washed and measured on millimetre paper in order to determine the root depth. The average root depth during each stage of growth was used to schedule irrigation. The same amount of water was given to all the treatments until the commencement of flowering when skipping of irrigation began. Rainfall was accommodated and used in the scheduling of irrigation in the days when it occurred in order to avoid over irrigation. Measurement of the soil moisture content was done prior to irrigation to fill the soil to field capacity. The net irrigation requirement of the crop was determined by [20]:

$$
d=R-\sum_{i=1}^{n} \frac{\left(M_{f c i}-M_{b i}\right)}{100} \times A_{i} \times D_{i}
$$

where $d$ is the net amount of irrigation applied, (mm), $\mathrm{R}$ is the rainfall (mm), $M_{f c i}$ is the field capacity moisture content in the ith layer $\left(\mathrm{m}^{3} \mathrm{~m}^{-3}\right)$. It was measured 2 days after irrigation, $M_{b i}$ is the moisture content before irrigation in the ith layer $\left(\mathrm{m}^{3} \mathrm{~m}^{-3}\right), A_{i}$ is the bulk density of the soil in the ith layer $\left(\mathrm{g} \mathrm{cm}^{-3}\right), D_{i}$ is the depth of the ith soil layer within the root zone $(\mathrm{mm}), \mathrm{n}$ is the number of soil layers in the root zone.

In the two seasons, the average numbers of weekly irrigations for $\mathrm{T}_{1111}, \mathrm{~T}_{0111}, \mathrm{~T}_{1011}$ were 13,12 and 12 , respectively, while for $\mathrm{T}_{1101}$ and $\mathrm{T}_{1110}$, they were 11 and 12 times.

\section{Leaf area index (LAI) and soil evaporation measurement}

Above and below photosynthetically active radiation (PAR) and leaf area index (LAI) were measured using an AccuPAR LP 80 (Decagon Devices, Inc., WA, USA) near noon until maturity at average intervals of 7 days from 14 DAP in both seasons. Ten measurements of the above and below PARs were taken from three replicates of each treatment by placing the probe (line sensor) perpendicularly to the rows above and below the plant canopy. The average value of LAIs measured was computed for each of the treatments. A total of 14 consecutive measurements of LAIs was made in each irrigation season. The 
daily LAI for each treatment was determined by interpolation of the measured values.

Daily evaporation was measured using a class A evaporation pan installed in the field. A time series graph of LAI versus DAP was developed from which the LAI of the crop at any period was determined. Assuming that the net radiation inside a canopy decreases according to the exponential function and that soil heat flux is neglected, daily actual evaporation of water from the cropped field was determined using the methods of Cooper et al. [21] and Lu et al. [22] which is expressed as:

$$
E_{a}=E X P(-\lambda \times L A I) \times E_{p}
$$

where $E_{a}$ is the actual evaporation from soil in a cropped plot $(\mathrm{mm}), \lambda$ is the average seasonal leaf extinction coefficient (0.46), $\mathrm{E}_{\mathrm{p}}$ is the pan evaporation $(\mathrm{mm})$.

Seasonal soil water evaporation (SEP) was determined by summing daily evaporation from emergence until maturity.

\section{Seasonal crop water use (SWU)}

The SWU was determined using the soil water balance approach [20]. Daily rainfall was measured on the field using rain gauges. Runoff was measured by placing a metallic box within an area of $0.716 \mathrm{~m}^{2}$ in two replicates and directed towards a graduated drum [23]. The contribution of groundwater was ignored because the groundwater table was deeper than $60 \mathrm{~m}$. The drainage below the root zone was considered negligible under drip irrigation [24]. The change in the moisture $( \pm \Delta s)$ at the root zone was determined from measurement of the soil moisture. Therefore, the crop water use $(\mathrm{mm})$ was determined as:

$$
S W U=I+R-R_{o} \pm \Delta S
$$

where SWU is the actual seasonal crop water use $(\mathrm{mm})$, I is the irrigation $(\mathrm{mm}), R$ is the rainfall $(\mathrm{mm}), R_{o}$ is the runoff $(\mathrm{mm}), \pm \Delta \mathrm{S}$ is the change in the soil moisture content $(\mathrm{mm})$.

Seasonal crop water use (SWU) was determined by adding the crop water use at each stage. Seasonal transpiration (STP) was determined from the difference between SWU and SEP [22]. Water productivity was determined by [25]:

$$
W P=\frac{Y}{S W U}
$$

where WP is the water productivity $\left(\mathrm{kg} \mathrm{ha}^{-1} \mathrm{~mm}^{-1}\right), \mathrm{Y}$ is the marketable crop yield $\left(\mathrm{kg} \mathrm{ha}^{-1}\right)$, SWU $=$ seasonal crop water use $(\mathrm{mm})$.

Similarly, irrigation water productivity (IWP) was determined by using the Equation:

$$
I W P=\frac{Y}{I W A}
$$

where IWP is the irrigation water productivity $\left(\mathrm{kg} \mathrm{ha}^{-1} \mathrm{~mm}^{-1}\right), \mathrm{Y}$ as defined previously, IWA is the seasonal irrigation water applied $(\mathrm{mm})$.

Economic water productivity was determined [26] by using:

$$
W P_{\text {economic }}=\frac{p \times Y}{S W U}
$$

where, $\mathrm{WP}_{\text {economic }}$ is the economic water productivity (US\$ ha ${ }^{-1} \mathrm{~mm}^{-1}$ ), $\mathrm{p}$ is the market price (US\$ ton ${ }^{-1}$ ), Y as defined previously.

In order to determine the crop coefficient factor, the difference $(\Delta)$ between the yields for the treatments where irrigation was skipped for 7 days every other week and that of FI was determined. The same procedure was used for the seasonal transpiration (STP).

\section{Economic analysis}

Economic analysis was done for the two seasons in order to know the profitability of using inline drip irrigation in the cultivation of the crop. The costs of the water tank plus plumbing work, drip lines and accessories and the pumping machine plus PVC hose remained unchanged. The costs of these items were spread over a period of 10 years. The costs of the following items vary from one season to the other due to the economic situation in the area: land preparation, seeds, herbicides, weeding, insecticides, harvesting, threshing and transportation. The researchers hired a plumber to assist in the setting up and coupling of the irrigation accessories. The water pumped from the stream by the researchers themselves was not paid for. The cost of pumping is basically the money spent on petrol and occasional maintenance of the $6.5 \mathrm{hp}$ pumping engine. The cost of pumping water ranged from US\$ $987 \mathrm{ha}^{-1}$ for FI to US\$ $675 \mathrm{ha}^{-1}$ for DI during seed filling. The addition of the costs of all the items above was used to determine the total cost of production for each treatment. Price of the crop was US\$ 541 per ton as at the time of harvest [27]. The product of the average seed yields and price per ton gave the total revenue for each treatment. The difference between total cost of production and gross returns gave the financial benefit or loss. English et al. [1] approach was used in explaining the scenario of water-limiting conditions.

\section{Water-limiting conditions}

Under the water-limiting situation, land is available but water is limited. In this case, additional land can be brought under irrigation if water is saved by practising DI. The irrigation plan that produces the optimum water and economic water productivity is considered to be the most promising. The trends of WP and IWP among the treatments were compared. The amounts of water saved 
per unit area during the deficit irrigation treatments and the possibility of increasing the opportunity costs of the irrigation water in the study area were examined. The potential increase in farm income from additional land is an opportunity cost of the water saved during DI.

\section{Statistical analysis}

The statistical software SAS was used for the data analysis. The analyses of variance (ANOVA) of the LAI, seed yields and $\mathrm{HI}$ were carried out by using the Duncan Multiple Range Test at significant level $\alpha=0.05$ and means were compared.

\section{Results and discussion} Leaf area index and dry biomass

In the first season, $\mathrm{T}_{1111}$ had the highest LAIs throughout the crop cycle while $\mathrm{T}_{1101}$ had the minimum LAIs during the seed filling and maturity as expected (Table 3 ). In the second season, the LAI for $\mathrm{T}_{1111}$ was lower compared with the first season. This is due to the difference in the weather conditions in the two seasons and water stress imposed on the crop. Peak LAIs for $\mathrm{T}_{1111}$ were 33, 36, 41 and $50 \%$ higher than for $\mathrm{T}_{0111} ; \mathrm{T}_{1110} ; \mathrm{T}_{1011}$ and $\mathrm{T}_{1101}$, respectively. Higher LAIs under $\mathrm{T}_{1111}$ resulted into formation of denser canopy with greater interception of the PAR and higher DBM. There was no significant difference $(\mathrm{p}>0.05)$ in the LAIs during seed filling for $\mathrm{T}_{0111}, \mathrm{~T}_{1011}$ and $\mathrm{T}_{1101} \cdot \mathrm{T}_{1101}$ had the lowest LAI because of the long duration of water stress imposed on it. Similarly, in the $2013 / 2014$ irrigation season, $\mathrm{T}_{1111}$ had the highest LAI at all stages of growth. The LAIs in the stated stages in the second season were lower than those for the first season. The crop reached the highest LAI in the first season during seed filling (86 DAP). DI during the seed filling in $\mathrm{T}_{1101}$ reduced the LAI significantly. This is because irrigation was skipped for 7 days every other week (total 21 days) during the mid season, unlike $\mathrm{T}_{0111}$ where irrigation was skipped for 1 week. The LAIs for $\mathrm{T}_{0111}, \mathrm{~T}_{1011}$ and $T_{1110}$ were not significantly different $(p>0.05)$ from one another at pod initiation and seed filling because the reduction in canopy caused by water stress during flowering had been compensated for when it was irrigated later in the season. However, in the second season, the crop reached peak LAIs during flowering (Table 3).

\section{Dry biomass}

There was seasonal variability in the effects of water stress on dry matter (Fig. 1). Compared with $\mathrm{T}_{1111}$, the DBM for $\mathrm{T}_{0111}$ reduced by an average of $11.7 \%(\mathrm{p}>0.05)$ due to water stress while at pod initiation, it reduced significantly $(\mathrm{p}<0.05)$ by an average of $21.7 \%$. Similarly, water stress during seed filling and commencement of maturity reduced DBM by seasonal average of $15 \%$ $(\mathrm{p}>0.05)$ and $28 \%(\mathrm{p}<0.05)$, respectively. DBM reached the peak during seed filling in 2013/2014 irrigation season unlike in the 2013 irrigation season when it reached the peak at maturity. This could be attributed to higher humidity and transpiration that supported biomass accumulation. DI during flowering reduced the number of seed per plant more than during seed filling. This was possibly due to reduction in the flower production and abortion of flower [28].

\section{Seasonal water use, dry matter and seed yield}

The least amount of water was used during the initial stage of the crop while the peak amount was used during

Table 3 LAI $\left(\mathrm{m}^{2} \mathrm{~m}^{-2}\right)$ during the crop cycle in the two seasons

\begin{tabular}{|c|c|c|c|c|}
\hline Treatment label & FL (R1) 49 DAP & PI (R3) 63 DAP & PF (R6) (86 DAP) & MT (R7-R8) (109 DAP) \\
\hline \multicolumn{5}{|l|}{2013} \\
\hline 1. $T_{1111}$ & $3.8 \pm 0.4^{\mathrm{a}}$ & $5.5 \pm 0.3^{\mathrm{a}}$ & $7.1 \pm 0.3^{\mathrm{a}}$ & $2.2 \pm 0.1^{\mathrm{a}}$ \\
\hline 2. $T_{0111}$ & $3.1 \pm 0.2^{a b}$ & $4.6 \pm 0.2^{b}$ & $4.8 \pm 0.4^{b}$ & $0.6 \pm 0.3^{c}$ \\
\hline 3. $T_{1011}$ & $2.8 \pm 0.2^{b}$ & $4.9 \pm 0.3^{a b}$ & $4.2 \pm 0.8^{b c}$ & $0.6 \pm 0.2^{c}$ \\
\hline 4. $T_{1101}$ & $2.7 \pm 0.5^{b}$ & $4.5 \pm 0.2^{b}$ & $3.6 \pm 0.2^{c}$ & $0.5 \pm 0.1^{c}$ \\
\hline 5. $T_{1110}$ & $3.3 \pm 0.7^{a b}$ & $4.8 \pm 0.6^{a b}$ & $4.5 \pm 0.2^{b}$ & $1.4 \pm 0.2^{b}$ \\
\hline \multicolumn{5}{|l|}{$2013 / 2014$} \\
\hline 1. $T_{1111}$ & $3.4 \pm 0.3^{\mathrm{a}}$ & $2.6 \pm 0.1^{\mathrm{a}}$ & $1.3 \pm 0.3^{\mathrm{a}}$ & $1.0 \pm 0.0^{\mathrm{a}}$ \\
\hline 2. $T_{0111}$ & $2.4 \pm 0.4^{a b}$ & $2.1 \pm 0.1^{b}$ & $1.0 \pm 0.0^{\mathrm{a}}$ & $0.7 \pm 0.0^{d}$ \\
\hline 3. $T_{1011}$ & $2.9 \pm 0.1^{a b c}$ & $2.3 \pm 0.2^{\mathrm{ab}}$ & $1.1 \pm 0.1^{\mathrm{a}}$ & $0.8 \pm 0.0^{b}$ \\
\hline 4. $T_{1101}$ & $3.2 \pm 0.4^{\mathrm{ab}}$ & $2.3 \pm 0.2^{\mathrm{ab}}$ & $1.0 \pm 0.0^{\mathrm{a}}$ & $0.4 \pm 0.0^{e}$ \\
\hline 5. $T_{1110}$ & $2.7 \pm 0.0^{b c}$ & $2.5 \pm 0.1^{a b}$ & $1.2 \pm 0.1^{\mathrm{a}}$ & $0.8 \pm 0.0^{c}$ \\
\hline
\end{tabular}

Means of the LAI with the same letter are not significantly different at $5 \%$ level based on Duncan multiple comparison of means.

FL flowering, PI Pod initiation, PF seed filling, MT maturity. 

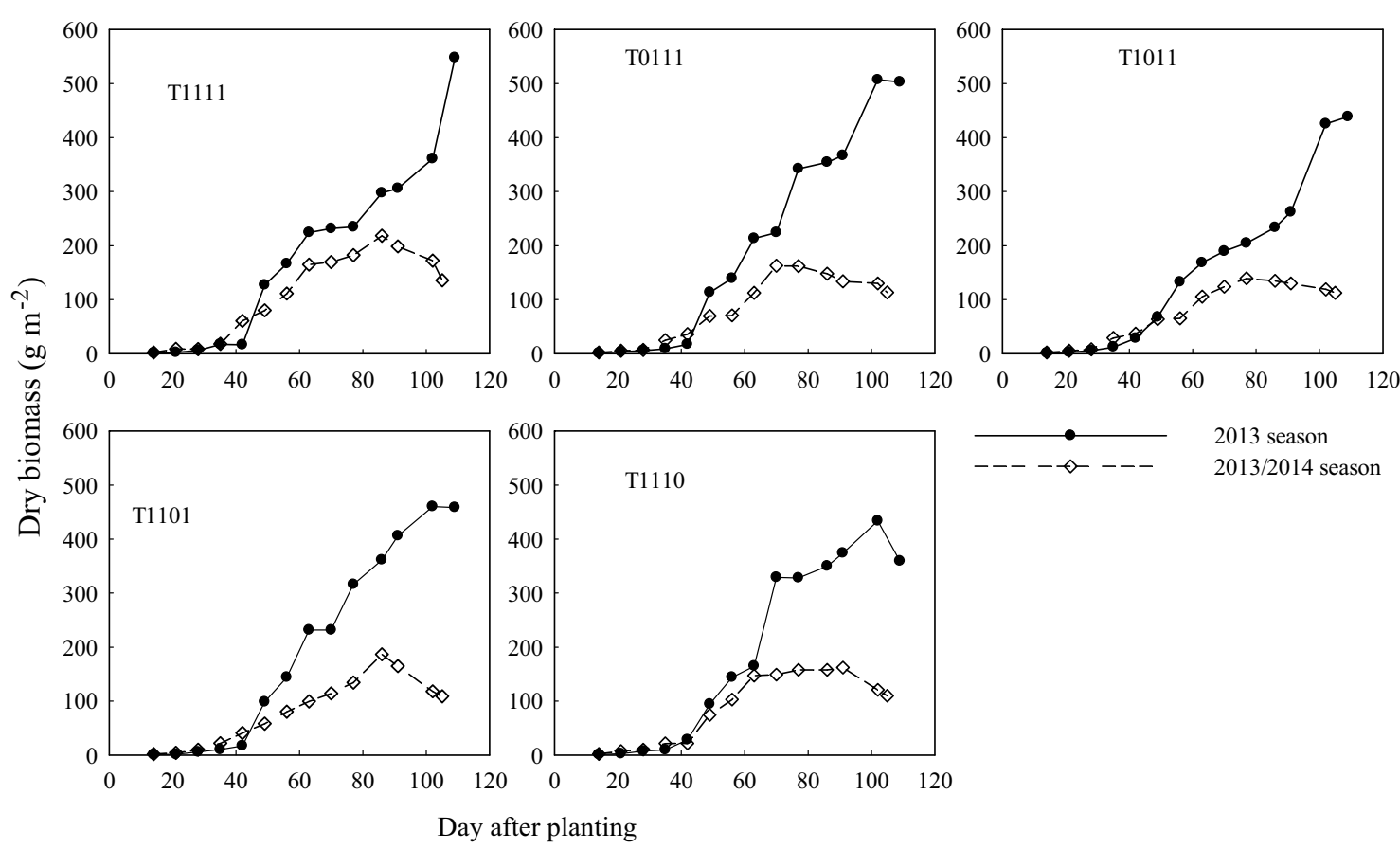

Fig. 1 Changes in the dry above-ground biomass for full and deficit irrigation in the two seasons.

the mid season characterized by flowering, pod initiation and filling (Table 4). $\mathrm{T}_{1111}$ had the highest SWU in both seasons as expected. For instance, the water use during the mid season for $\mathrm{T}_{1111}$ was 8.8, 15.8, 19.0 and $20.9 \%$ higher than the water used for $\mathrm{T}_{1110}, \mathrm{~T}_{1011}, \mathrm{~T}_{1101}$ and $\mathrm{T}_{0111}$, respectively. Similarly in the $2013 / 2014$ season, the water use for $\mathrm{T}_{1111}$ was 6.3, 7.9, 5.6 and $43.8 \%$ higher than the use for $\mathrm{T}_{0111}, \mathrm{~T}_{1011}, \mathrm{~T}_{1110}$ and $\mathrm{T}_{1101}$. The relationship between yield and SWU is of importance to farmers and other stakeholders in the irrigation industry because it is used in evaluating the effects of yield loss at different levels of water use, especially under limited water supply. The linear equations relating the seed yields, dry matter and SWU in both seasons are as follows:

Table 4 Growth stages, crop water use $(\mathrm{mm})$ and number of irrigations in the both seasons

\begin{tabular}{|c|c|c|c|c|c|c|c|}
\hline Treatment & $\begin{array}{l}\text { Establishment } \\
(00-25)\end{array}$ & $\begin{array}{l}\text { Vegetative } \\
(26-58)\end{array}$ & $\begin{array}{l}\text { Mid-season } \\
(59-100)\end{array}$ & $\begin{array}{l}\text { Late season } \\
(101-112)\end{array}$ & $\begin{array}{l}\text { Seasonal crop } \\
\text { water use }(\mathrm{mm})\end{array}$ & $\begin{array}{l}\text { No. of weekly } \\
\text { irrigation }\end{array}$ & $\begin{array}{l}\text { No. of days irriga- } \\
\text { tion was skipped }\end{array}$ \\
\hline \multicolumn{8}{|l|}{2013} \\
\hline 1. $T_{1111}$ & 35 & 173 & 273 & 42 & 523 & 09 & - \\
\hline 2. $T_{0111}$ & 35 & 170 & 216 & 42 & 463 & 08 & 7 \\
\hline 3. $T_{1011}$ & 35 & 173 & 230 & 42 & 480 & 08 & 7 \\
\hline 4. $T_{1101}$ & 35 & 173 & 221 & 36 & 465 & 08 & 14 \\
\hline \multirow[t]{2}{*}{ 5. $T_{1110}$} & 35 & 173 & 249 & 38 & 495 & 08 & 7 \\
\hline & $(00-25)$ & $(26-57)$ & $(58-100)$ & $(101-109)$ & SWU & & \\
\hline \multicolumn{8}{|l|}{$2013 / 2014$} \\
\hline 1. $T_{1111}$ & 29 & 130 & 304 & 44 & 507 & 16 & - \\
\hline 2. $T_{0111}$ & 29 & 123 & 285 & 44 & 481 & 15 & 7 \\
\hline 3. $T_{1011}$ & 29 & 101 & 280 & 44 & 454 & 15 & 7 \\
\hline 4. $T_{1101}$ & 29 & 130 & 171 & 34 & 364 & 13 & 21 \\
\hline 5. $T_{1110}$ & 29 & 129 & 287 & 22 & 467 & 15 & 7 \\
\hline
\end{tabular}

The duration of each phenologic stage is in parentheses. 
$Y D=11.1 \times S W U-3390 \quad r^{2}=0.40 \quad(p=0.07)$

$D M=17.4 \times S W U-5570 \quad r^{2}=0.20 \quad(p=0.18)$

The relationships indicate that seed yields and dry matter increased with increase in the applied water. Equation (7) implies that a threshold of about $306 \mathrm{~mm}$ of water is required to initiate seed yield and that an increment of $50 \mathrm{~mm}$ of SWU will increase yield by $555 \mathrm{~kg} \mathrm{ha}^{-1}$. Similarly, Eq. (8) implies that a threshold of about $321 \mathrm{~mm}$ of water is required to initiate an increase in dry matter and that a dry matter of about $870 \mathrm{~kg} \mathrm{ha}^{-1}$ will be obtained for every increment of $50 \mathrm{~mm}$ of SWU. These dry matter and seed yields are significant. The linear model reported by Nielsen [29] (Eq. 9) predicted similar yield that is about 15\% higher than the yield predicted in this study.

$$
\mathrm{Y}=65.3 \times \mathrm{SWU}-1130
$$

where, $\mathrm{Y}$ is the yield $\left(\mathrm{kg} \mathrm{ha}^{-1}\right)$, SWU is the seasonal crop water use $(\mathrm{mm})$.

Exponential model of the yields and SWU $\left(\mathrm{r}^{2}=0.48\right)$ in this study (Eq. 10) implies that SWU will produce a yield threshold of about $45 \mathrm{~kg} \mathrm{ha}^{-1}$ and thereafter seasonal increment of $50 \mathrm{~mm}$ will produce yield at an exponential rate:

$$
Y=45.4 e^{0.01 \times S W U}
$$

\section{Relationship between yield decrease and decrease} in evapotranspiration

The regression equation obtained using the popular water production function [7] was:

$$
\left(1-\frac{Y_{a}}{Y_{m}}\right)=2.24 \times\left(1-\frac{S W U_{a}}{S W U_{m}}\right)
$$

where, $\mathrm{SWU}_{\mathrm{a}}$ is the seasonal crop water use under DI $(\mathrm{mm}), \mathrm{SWU}_{\mathrm{m}}$ is the seasonal crop water use for $\mathrm{T}_{1111}$ $(\mathrm{mm}), \mathrm{Y}_{\mathrm{a}}$ is the yields obtained under DI $\left(\mathrm{kg} \mathrm{ha}^{-1}\right), \mathrm{Y}_{\mathrm{m}}$ is the yields obtained for $\mathrm{T}_{1111}\left(\mathrm{~kg} \mathrm{ha}^{-1}\right)$.

The crop response factor is expressed by the slope of the regression equation. The seasonal $\mathrm{k}_{\mathrm{y}}$ of 2.24 in this study is higher than 0.85 for soybean under DI [30]. This implies that the moisture stress imposed on the crop was severe and the rate of decrease in seed yield is proportionally higher than the relative deficit SWU. Reduction in the seed yields of soybean is inevitable under DI [31]. In the 2013 irrigation season, yield reductions were 9.3, 25.4, 41.8 and 25.7\% $(\mathrm{p}<0.05)$ for $\mathrm{T}_{0111}, \mathrm{~T}_{1011}, \mathrm{~T}_{1101}$ and $\mathrm{T}_{1110}$, respectively. Similarly, in the $2013 / 2014$ irrigation season, yield reductions for $\mathrm{T}_{0111}, \mathrm{~T}_{1011}, \mathrm{~T}_{1101}$ and $\mathrm{T}_{1110}$ were 28.3, 18.4, 53.9 and 23.0\%, respectively. Average seasonal reductions in the seed yields were 18.8 and $21.9 \%$ $(\mathrm{p}>0.05)$ for $\mathrm{T}_{0111}$ and $\mathrm{T}_{1011}$ (Table 4). Similarly, average seasonal and significant reductions were $47.9(\mathrm{p}<0.05)$ and $24.4 \%(\mathrm{p}>0.05)$ for $\mathrm{T}_{1101}$ and $\mathrm{T}_{1110}$. This implies that DI during the seed filling and commencement of maturity in soybeans could lead to a reduction in seed yields by half.

The seed yields for full irrigation in both seasons are significantly higher than those subjected to DI. This result is similar to the findings of Sincik et al. [15] that non-irrigated and all deficit irrigation treatments significantly reduced biomass and seed yield and yield components. The $T$ test at $95 \%$ confidence limit shows that the average seasonal seed yields are significantly different $(p<0.05)$. The yields of soybean in this study especially for full irrigation and DI compare well with the data in literature. For instance, yields for T1111 are between 3.6 and to $3.7 \mathrm{t} \mathrm{ha}^{-1}$ for fully irrigated soybean and higher than the average seed yields under different DI [32]. The yield range in this study is similar to $2.16-3.93 \mathrm{t} \mathrm{ha}^{-1}$ and $1.98-3.59 \mathrm{t} \mathrm{ha}^{-1}$ for DI irrigation [33]; 2.3 to $3.5 \mathrm{t} \mathrm{ha}^{-1}$ under different DI [13] and 2.07 to $3.76 \mathrm{t} \mathrm{ha}^{-1}$ [15].

\section{Soil water balance}

The lengths of each stage and rainfall event that occurred during the crop cycle were responsible for the differences in the total amount of water applied (Table 5). There were significant differences $(\mathrm{P}<0.05)$ in the SEP, STP, and SWU in the 2013 irrigation season indicating that there is variability in the water used under DI. $\mathrm{T}_{1111}$ had the peak STP and SWU while $\mathrm{T}_{1101}$ had the minimum STP in both seasons. Higher STP and SET for $\mathrm{T}_{1111}$ is expected because it was irrigated more often than any other treatment during the growing season (Table 5). SEP reduced significantly by $30.9,9.1,3.0$ and $4.2 \%$ for $\mathrm{T}_{1111}$, $\mathrm{T}_{0111}, \mathrm{~T}_{1101}$ and $\mathrm{T}_{1110}$, respectively, in the 2013 irrigation season compared with $\mathrm{T}_{1011}$. Similarly, in the 2013/2014 irrigation season, SEP reduced by $15.5,3.60,6.00$, and $2.70 \%$ for $\mathrm{T}_{1111}, \mathrm{~T}_{0111}, \mathrm{~T}_{1011}$ and $\mathrm{T}_{1110}$, respectively, compared with $\mathrm{T}_{1101} \cdot \mathrm{T}_{1111}$ received highest amount of water that favoured denser canopy (leaf) and higher LAIs than other treatments during the growing seasons. SEP was $21.8,31.9,32.4,34.4$ and $34.4 \%$ of the SWU for $\mathrm{T}_{1111}$, $\mathrm{T}_{1110}, \mathrm{~T}_{0111}, \mathrm{~T}_{1011}$ and $\mathrm{T}_{1101}$ in the 2013 irrigation season. In the 2013/2014 season, evaporation was 56.0, 67.4, 69.6, 70.0 , and $92.3 \%$ of the SWU. SEP constituted an average of $71 \%$ of the SWU in the 2013/2014 irrigation season unlike in the 2013 irrigation season when it was $31 \%$ of the SWU. Higher proportion of the SWU partitioned towards non-productive evaporation was responsible for the lower seed yields in the second irrigation season (Table 5). STP in the 2013 irrigation season reduced significantly by $23.5,23.0,46.9$, and $17.6 \%(\mathrm{p}<0.05)$ for $\mathrm{T}_{0111}, \mathrm{~T}_{1011}, \mathrm{~T}_{1101}$ and $\mathrm{T}_{1110}$, respectively, due to water stress. Similarly, in the $2013 / 2014$ season, STP reduced 
Table 5 Seasonal evaporation, transpiration, crop water use and seed yields in the two seasons

\begin{tabular}{|c|c|c|c|c|c|c|}
\hline Treatment label & SEP (mm) & STP (mm) & SET (mm) & $\Delta$ SET & $\Delta$ Yield & Yield $\left(\mathrm{t} \mathrm{ha}^{-1}\right)$ \\
\hline \multicolumn{7}{|l|}{2013} \\
\hline 1. $T_{1111}$ & $114^{d}$ & $409^{a}$ & $523^{a}$ & 0.00 & 0.00 & $3.11^{\mathrm{a}}$ \\
\hline 2. $T_{0111}$ & $150^{c}$ & $313^{c}$ & $463^{d}$ & 0.11 & 0.09 & $2.82^{\mathrm{a}}$ \\
\hline 3. $T_{1011}$ & $165^{a b}$ & $315^{c}$ & $480^{c}$ & 0.08 & 0.25 & $2.32^{\mathrm{ab}}$ \\
\hline 4. $T_{1101}$ & $160^{a b}$ & $217^{d}$ & $465^{d}$ & 0.11 & 0.42 & $1.81^{\mathrm{b}}$ \\
\hline 5. $T_{1110}$ & $158^{b}$ & $337^{b}$ & $495^{\mathrm{b}}$ & 0.05 & 0.32 & $2.31^{\mathrm{ab}}$ \\
\hline \multicolumn{7}{|l|}{$2013 / 2014$} \\
\hline 1. $T_{1111}$ & $284^{b}$ & $223^{\mathrm{a}}$ & $507^{\mathrm{a}}$ & 0.00 & 0.00 & $1.52^{\mathrm{a}}$ \\
\hline 2. $T_{0111}$ & $324^{\mathrm{a}}$ & $157^{b}$ & $481^{b}$ & 0.05 & 0.28 & $1.09^{\mathrm{ab}}$ \\
\hline 3. $T_{1011}$ & $316^{\mathrm{a}}$ & $138^{c}$ & $454^{d}$ & 0.11 & 0.19 & $1.24^{\mathrm{a}}$ \\
\hline 4. $T_{1101}$ & $336^{\mathrm{a}}$ & $28^{\mathrm{d}}$ & $364^{e}$ & 0.28 & 0.54 & $0.70^{\mathrm{b}}$ \\
\hline 5. $T_{1110}$ & $327^{a}$ & $140^{c}$ & $467^{c}$ & 0.08 & 0.23 & $1.17^{\mathrm{ab}}$ \\
\hline
\end{tabular}

Seasonal evaporation of water from soil (SEP), Seasonal transpiration (STP), Seasonal crop water use (SET); difference between SET and seed yield for FI and each of other treatments $(\Delta)$. Means of the yields, SEP, STP, SET and yield with the same letter are not significantly $(P>0.05)$ different at $5 \%$ level based on Duncan multiple comparison of means.

significantly by $29.6,38.1,87.4$, and $37.2 \%(\mathrm{p}<0.05)$ for $\mathrm{T}_{0111}, \mathrm{~T}_{1011}, \mathrm{~T}_{1101}$ and $\mathrm{T}_{1110}$, respectively. Average STP for the 2013 and 2013/2014 irrigation seasons constituted about 70 and $30 \%$, respectively, of the SWU.

By using a linear model (Eq. 12) STP and seed yield in the two seasons were significantly correlated $\left[\mathrm{r}^{2}=0.92\right.$, Standard error of Estimate (SEE) $\left.\left.=23.8 \mathrm{~kg} \mathrm{ha}^{-1}\right)\right]$ :

$$
\mathrm{Y}\left(\mathrm{kg} \mathrm{ha}^{-1}\right)=0.67 \times \operatorname{STP}(\mathrm{mm})+29.5
$$

This means that $92 \%$ of the variability in the seed yield can be explained by STP and that for every increment of $10 \mathrm{~mm}$ in STP, seed yield will increase by $6.7 \mathrm{~kg} \mathrm{ha}^{-1}$. Reduction in the STP under DI was responsible for the lower yields compared with full irrigation. Across the years and water regimes, LAIs during seed filling and average seed yields were significantly correlated (Fig. 2), $\left(\mathrm{p}<0.05, \mathrm{SEE}=25.2 \mathrm{~kg} \mathrm{ha}^{-1}\right)$. The model implies that potential yield of $3500 \mathrm{~kg} \mathrm{ha}^{-1}$ was obtainable at LAI of $11.5 \mathrm{~m}^{2} \mathrm{~m}^{-2}$. However, this could not be reached as a result of water stress and environmental conditions. $\mathrm{T}_{1111}$ had the highest LAI of $7.10 \mathrm{~m}^{2} \mathrm{~m}^{-2}$ for the first irrigation season. LAI and STP were significantly correlated $(\mathrm{p}<0.05$, SEE 53.6). This indicates that $79 \%$ of the variability in the STP is accounted for by LAI. SWU and LAIs were not significantly correlated over the years $\left(\mathrm{r}^{2}=0.25\right.$, $\mathrm{p}>0.05)$. The SWU for soybean under irrigated conditions and other crops varied from one area and season to the other [34]. SWU of 364-523 mm for both irrigation seasons fall within the range in literature. SWU of $554-721 \mathrm{~mm}$ was reported by Lamm et al. [34] and 513-1,261 $\mathrm{mm}$ by Gercek et al. [17]. Similarly, Candogan et al. [33] reported SWU between 394 and $802 \mathrm{~mm}$ and 351-841 mm under different levels of DI. Dogan et al. [32] reported 574-619 $\mathrm{mm}$ for fully irrigated conditions. The yield range in this study is similar to $2.16-3.93$ and
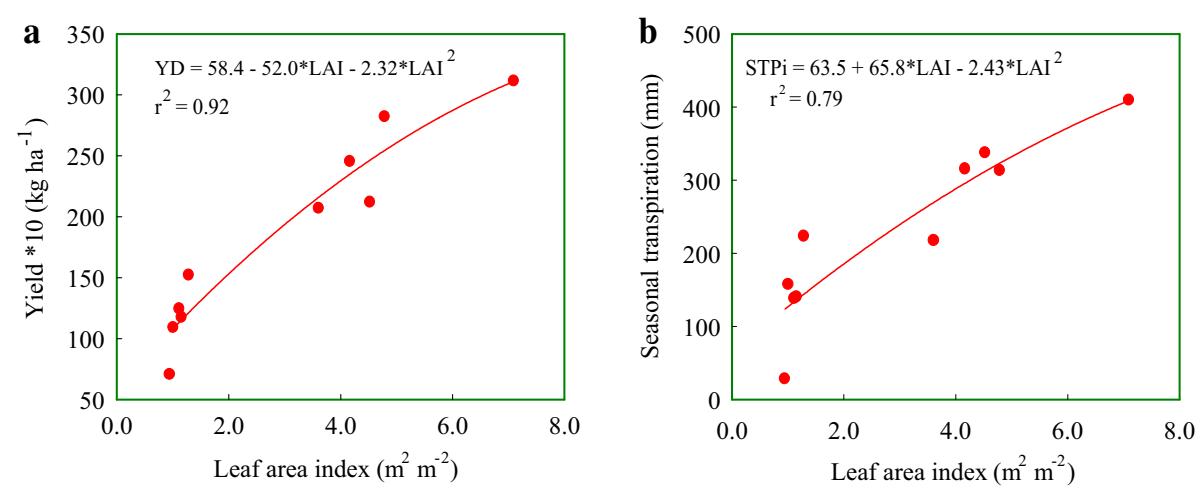

Fig. 2 Relationship between LAls and a seed yield; b STP in the two seasons. 
1.98-3.59 $\mathrm{t} \mathrm{ha}^{-1}$ [33]; 2.3-3.5 $\mathrm{t} \mathrm{ha}^{-1}$ under different DI [13]) and 2.07-3.76 $\mathrm{tha}^{-1}[15]$.

\section{Water productivity and irrigation water productivity} WP in the 2013 season ranged from $3.89 \mathrm{~kg} \mathrm{ha}^{-1} \mathrm{~mm}^{-1}$ for $\mathrm{T}_{1101}$ to $6.09 \mathrm{~kg} \mathrm{ha}^{-1} \mathrm{~mm}^{-1}$ for $\mathrm{T}_{0111}$ while IWP for the same treatments ranged from $8.9 \mathrm{~kg} \mathrm{ha}^{-1} \mathrm{~mm}^{-1}$ for $\mathrm{T}_{1110}$ to $14.0 \mathrm{~kg} \mathrm{ha}^{-1} \mathrm{~mm}^{-1}$ for $\mathrm{T}_{0111}$ (Table 6). The WPs in this study fall within the range of 4.4 to $5.1 \mathrm{~kg} \mathrm{ha}^{-1} \mathrm{~mm}^{-1}$ for soybean [35]. $\mathrm{T}_{0111}$ gave the highest IWP in the first season, which was $15 \%$ higher than that of T1111. This trend supports Howell et al. [36], who stated that while maximum WP tends to occur at maximum SWU, maximum IWP usually occurs at SWU less than the maximum. Based on this, Howell et al. [36] suggested that irrigating to achieve the maximum grain yield and SWU would not be the most efficient use of irrigation water. The results obtained in this study show that IWP of soybeans can be increased if irrigation is skipped during flowering for seven days. $\mathrm{T}_{0111}$ had the highest WP and IWP while $\mathrm{T}_{1101}$ had the minimum in the 2013 irrigation season.

However, in the 2013/2014 irrigation season, $\mathrm{T}_{1111}$ had the peak WP and IWP while $\mathrm{T}_{1101}$ had the minimum WP and IWP. The result indicates that in water limited conditions, skipping of irrigation every other week during flowering, can be used to increase WP and IWP of soybeans. However, skipping of irrigation at seed filling $\mathrm{T}_{1101}$ will greatly reduce the seed yields. Pooled over the seasons, both WP $\left(\mathrm{r}^{2}=0.98, \mathrm{p}<0.05\right.$, SEE $\left.=13.2 \mathrm{~kg} \mathrm{ha}^{-1}\right)$ and seed yield are linearly and significantly correlated:

$$
\mathrm{Y}\left(\mathrm{kg} \mathrm{ha}^{-1}\right)=51.1 * \mathrm{WP}\left(\mathrm{kg} \mathrm{ha}^{-1} \mathrm{~mm}^{-1}\right)-13.8
$$

This equation indicates that skipping irrigation for a week, that is increasing WP does not substantially affect seed yields. The results obtained show that WP and IWP for a high yielding variety such as (TGX 1448 2E) can be improved by using drip irrigation. The WPs fall within $4.58-5.58 \mathrm{~kg} \mathrm{ha}^{-1} \mathrm{~mm}^{-1}[15]$.

\section{Water productivity and harvest index}

HI reduced significantly $(\mathrm{p}<0.05)$ by $15.1 \%$ for $\mathrm{T}_{1111}$, 5.35 , and $9.60 \%$ for $\mathrm{T}_{1011}$ and $\mathrm{T}_{1110}$, respectively, compared with $\mathrm{T}_{0111}$ in the first season (Table 6). Similarly, HI reduced significantly by 32.4 and $12.2 \%$ for $\mathrm{T}_{1101}$ and $\mathrm{T}_{0111}$, respectively, whereas the reductions were 13.3 and $15.0 \%$ for $\mathrm{T}_{1011}$ and $\mathrm{T}_{1110}$ in 2013/2014 season. Substantial reduction in $\mathrm{HI}$ for $\mathrm{T}_{1101}$ was due to the reduction in STP because of consecutive depletion of the moisture in the root zone, which aborted fruits set, reduced fruit filling and hence reduced the yield. This trend shows that water stress during seed filling can reduce significantly the HI of soybean. Pooled over the years, WP and IWP were significantly correlated with HI $(\mathrm{p}<0.05)$, for WP $(\mathrm{SEE}=1.12)$ and for IWP (SEE $=3.36)$, respectively. This indicates that $\mathrm{HI}$ accounts for 53 and $44 \%$ of the variability in WP and IWP, respectively. According to the models, the minimum permissible HIs for the cultivar under investigation were 33.2 and $40.5 \%$ for WP and IWP. Improvement in the WPs and IWPs in this study was due to improved HIs under DI. Based on the data, it can be inferred that the cultivar TGX $14482^{\mathrm{E}}$ had efficient canopy in producing seeds. Results of this study are in agreement with Neyshabouri and Harfield [37] and Westgate et al. [38] who suggested that WP of soybeans could be improved by increasing its HI.

\section{Economic evaluation}

The outcome of the economic evaluation of the full and deficit irrigation cultivations under land- and water-limiting conditions is shown in Table 7 . The average cost of producing 1.26 to $2.32 \mathrm{t} \mathrm{ha}^{-1}$ was between US\$ 5,700 to 6,010 . Skipping of weekly irrigation during flowering, pod initiation and maturity reduced the cost of production by $1.33 \%$ while it was reduced by $5.16 \%$ during seed filling. The gross revenue also ranged between US\$ 680 to 1,300 . The loss incurred was between US\$ 4,710 and 5,020. It increased by $6.18 \%$ DI during seed filling. This indicates that the use of inline drip irrigation is not economically sustainable for commercial production of soybeans in the study area. For the purpose of making decisions, factors

Table 6 Water productivity, irrigation water productivity and harvest index for full and DI

\begin{tabular}{|c|c|c|c|c|c|c|}
\hline \multirow[t]{2}{*}{ Treatment Label } & \multicolumn{3}{|c|}{2013 irrigation season } & \multicolumn{3}{|c|}{$2013 / 2014$ irrigation season } \\
\hline & WP (kg ha mm $\mathrm{mm}^{-1}$ ) & IWP (kg ha mm ${ }^{-1}$ ) & HI (\%) & 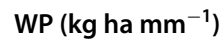 & IWP (kg ha $\mathrm{mm}^{-1}$ ) & $\mathrm{HI}(\%)$ \\
\hline 1. $T_{1111}$ & 5.95 & 11.9 & $61.3^{\mathrm{abc}}$ & 3.00 & 3.32 & $63.9^{\mathrm{a}}$ \\
\hline 2. $T_{0111}$ & 6.09 & 14.0 & $65.9^{\mathrm{a}}$ & 2.26 & 2.52 & $56.1^{\mathrm{ab}}$ \\
\hline 3. $T_{1011}$ & 5.11 & 11.2 & $62.4^{\mathrm{ab}}$ & 2.74 & 3.08 & $55.4^{\mathrm{ab}}$ \\
\hline 4. $T_{1101}$ & 3.89 & 8.9 & $56.0^{c}$ & 1.93 & 2.24 & $43.2^{b}$ \\
\hline 5. $T_{1110}$ & 4.66 & 9.9 & $59.6^{\mathrm{bc}}$ & 2.51 & 2.81 & $54.3^{\mathrm{ab}}$ \\
\hline
\end{tabular}

Means of the $\mathrm{HI}$ with the same letter are not significantly $(\mathrm{P}>0.05)$ different at $5 \%$ level based on Duncan multiple comparison of means. 
Table 7 Economic analysis of the use of drip method in cultivating soybean under full and DI conditions

\begin{tabular}{|c|c|c|c|c|c|}
\hline Treatment & Yield (t ha ${ }^{-1}$ ) & $\begin{array}{l}\text { Total cost of production } \mathrm{ha}^{-1} \\
\left.\text { (US } \$ \times 10^{3}\right)\end{array}$ & $\begin{array}{l}\text { Total revenue } \\
\left(\text { US } \$ \times 10^{3}\right)\end{array}$ & Loss (US\$) $\times 10^{3}$ & $\begin{array}{l}\text { Economic productivity } \\
\text { (US\$ } \mathrm{ha}^{-1} \mathrm{~mm}^{-1} \text { ) }\end{array}$ \\
\hline 1. $T_{1111}$ & 2.32 & 6.01 & 1.30 & 4.71 & 2.42 \\
\hline 2. $T_{0111}$ & 1.96 & 5.93 & 1.06 & 4.87 & 2.26 \\
\hline 3. $T_{1011}$ & 1.78 & 5.93 & 0.96 & 4.97 & 1.83 \\
\hline 4. $T_{1101}$ & 1.26 & 5.70 & 0.68 & 5.02 & 1.57 \\
\hline 5. $T_{1110}$ & 1.74 & 5.93 & 0.94 & 4.99 & 1.94 \\
\hline
\end{tabular}

such as the land productivity, WP, IWP and revenues for each irrigation strategy need to be given consideration. Average seasonal WP for FI was $4.48 \mathrm{~kg} \mathrm{ha}^{-1} \mathrm{~mm}^{-1}$ while it was $2.91 \mathrm{~kg} \mathrm{ha}^{-1} \mathrm{~mm}^{-1}$ for DI during seed filling. However, DI at flowering had the average maximum IWP of $8.26 \mathrm{~kg} \mathrm{ha}^{-1} \mathrm{~mm}^{-1}$ and DI during seed filling had the average minimum IWP of $5.57 \mathrm{~kg} \mathrm{ha}^{-1} \mathrm{~mm}^{-1}$. This indicates that FI more enhances WP and IWP of the crop than DI. High WP and IWP indices are of little interest if they are not associated with acceptable seed yield, production cost, and total revenue [39]. Irrigation water was most productive by skipping it every other week during flowering than any other stage. Interestingly it was associated with a relatively good average seed yield of $1.96 \mathrm{t} \mathrm{ha}^{-1}$ compared to $2.32 \mathrm{t} \mathrm{ha}^{-1}$ for FI. WP $\mathrm{Wconomic}$ was higher under FI than DI because of higher seed yield under FI.

\section{Water limited conditions}

Average seasonal economic water productivity of 2.42 US\$ $\mathrm{ha}^{-1} \mathrm{~mm}^{-1}$ under FI was higher than those of $\mathrm{T}_{0111}, \mathrm{~T}_{1110}, \mathrm{~T}_{1011}$, and $\mathrm{T}_{1101}$ by $6.7,19.9,24.3$ and $35.0 \%$, respectively (Table 7 ). The trend of increase shows that economic water productivity increases with the amount of water due to evapotranspiration. The cost of drip lines and their accessories constituted about $36.9-41.3 \%$ of the total cost of production. The skipping of irrigation for 7 days in $\mathrm{T}_{0111}, \mathrm{~T}_{1011}$ and $\mathrm{T}_{1110}$ reduced the cost of production by $1.33 \%$ while the skipping of irrigation for 21 days $\left(\mathrm{T}_{1101}\right)$ reduced the cost of production by $5.16 \%$ compared to $\mathrm{T}_{1111}$.

Shortage of water is often a constraint in crop production especially in dry seasons. In such water-limiting conditions, the water saved by DI can be used to irrigate additional land and thereby increasing farm income [1, 40]. Skipping of irrigation for 7 days every other week during flowering, pod initiation, and maturity conserved about $8.23,12.2$ and $11.4 \mathrm{~L}$ of water per $\mathrm{m}^{2}$, respectively. DI for 21 days during seed filling conserved $14.1 \mathrm{~L} \mathrm{~m}^{-2}$ $\left(141 \mathrm{~mm} \mathrm{ha}^{-1}\right)$. It constitutes $22.1 \%$ of average SWU for FI to produce $2.31 \mathrm{t} \mathrm{ha}^{-1}$ and 23.7 to $27.5 \%$ for DI to produce $1.26-1.96 \mathrm{t} \mathrm{ha}^{-1}$. The water conserved could be used for increasing land productivity for soybeans or for cultivating other crops such as vegetables in addition to soybeans during dry seasons in the study area. Under such conditions, skipping of irrigation during the stated reproductive stages is an appropriate irrigation strategy.

Despite higher yields in $\mathrm{T}_{1111}$, the maximum revenue of US\$ 1300 could not provide financial benefit let alone $\mathrm{T}_{1101}$ that received the minimum water in the two seasons (Table 6). This clearly shows that the use of drip irrigation in the cultivation of the crop is not financially sustainable for a peasant farmer despite the spread of the fixed cost over 10 years. A peasant farmer may only benefit from the use of drip lines after several years of continuous cultivation of the crop, adequate maintenance of the facility or if the entire fixed cost is carried by the government or donor agencies. The production of drip lines locally using less expensive and durable materials could reduce the total cost of production during irrigation. The financial benefits at the end of a cropping season depend on strategies used in reducing the cost of production and the available price of the crop in the market.

\section{Conclusion}

Assessment of crop water and economic productivity of drip irrigation for soybean was carried out in Ile-Ife during the 2013 and 2013/2014 dry seasons. Results show that deficit irrigation reduced leaf area index, transpiration, number of seeds per plant, seasonal water use and seed yield. Duration of the growth stages and the total number of days in which irrigation was skipped also contributed to the severity of the effects of deficit irrigation on LAI, dry matter, seasonal water use and seed yields. Due to the long period of seed filling (average of 35 days in the two seasons), DI reduced LAI and dry matter such that further application of water during the short period of maturity could not compensate for the reduction and thereby resulted in significant reduction in the seed yield. Although deficit irrigation during flowering and pod initiation reduced LAI, compensation was made after subsequent water application during the season and the effects on the dry matter and seed yield was minimal. Subjection of soybeans to water stress for consecutive 7 days during flowering and total of 21 days during seed filling did not significantly reduce the number of seeds per pod. Peak 
water productivity was obtained under full irrigation. Water and irrigation water productivity may be increased by skipping irrigation 7 days every other week during pod initiation and commencement of maturity. The water conserved during deficit irrigation could be used to increase opportunity cost. If the primary objective is to increase the seed yield or land productivity of soybeans, full irrigation is hereby recommended. The outcomes of the economic analysis under water-limiting conditions provide information for policy makers at basin scale for formulating improved and efficient water management plans under similar weather conditions. The results will be beneficial in adopting deficit irrigation in a manner that will improve crop water and economic productivity on local and international scales.

\begin{abstract}
Abbreviations
Dl: deficit irrigation; Fl: full irrigation; WP: water productivity; IWP: irrigation water productivity; DOY: day of the year; DAP: day after planting; DBM: dry biomass; PAR: photosynthetically active radiation; LAl: leaf area index; HI: harvest index; SEP: seasonal evaporation from soil; STP: seasonal transpiration; SWU: seasonal water use; IWA: irrigation water applied; ANOVA: analysis of variance; SEE: standard error of estimate.
\end{abstract}

\section{Authors' contributions}

OB wrote the proposal and designed the experiment, carried out the field work, analysed, interpreted the data collected from the field and wrote the manuscript. BS coordinated and did oversee the entire research activities, participated in the design, corrected the proposal, and revised the manuscript. $\mathrm{KO}$ participated in the design, revised the proposal, supervised the field work in Nigeria, and corrected the manuscript. KC revised the proposal and corrected the manuscript. All authors read and approved the final manuscript.

\section{Author details}

${ }^{1}$ Department of Agricultural and Environmental Engineering, Obafemi Awolowo University, Ile-Ife, Nigeria. ${ }^{2}$ Chairgroup, Land and Water Development, UNESCO-IHE Institute for Water Education, Delft, The Netherlands.

\section{Acknowledgements}

We would like to thank Prof. O.O. Jegede of the Department of Physics, Obafemi Awolowo University, Nigeria for sharing meteorological data with us and Mr. A. Jejelola of the Institute for Agricultural Research and Training (IAR\&T) Ibadan, Obafemi Awolowo University House Station for providing technical assistance during the fieldwork. We are sincerely grateful to Dutch government under Netherlands Fellowship Programme (NFP) for providing the funding for this project. We would also like to thank the reviewer and editors of the journal for their constructive and objective criticisms and suggestions for improvement of the manuscript.

\section{Compliance with ethical guidelines}

\section{Competing interests}

The authors declare that they have no competing interests.

Received: 28 November 2014 Accepted: 28 July 2015

Published online: 19 August 2015

\section{References}

1. English MJ, Musick JT, Murty VV (1990) Deficit irrigation. In: Hoffman GJ, Towell TA, Solomon KH (eds) Management of farm irrigation systems. St. Joseph, Michigan
2. Pereira LS, Oweis T, Zairi A (2002) Irrigation management under water scarcity. Agric Water Manage 57:175-206

3. Kirda C (2002) Deficit irrigation scheduling based on plant growth stages showing water stress tolerance. Food and Agricultural Organization of the United Nations, Deficit Irrigation Practices, Water Reports, 22, 102

4. Zhang J, Sui X, Li B, Su B, Li J, Zhou D (1998) An improved water-use efficiency for winter wheat grown under reduced irrigation. Field Crops Res 59:91-98

5. Specht JE, Elmore RW, Eisenhauer DE, Klocke NW (1989) Growth stage scheduling criteria for sprinkler-irrigated soybeans. Irrig Sci 10:99-111

6. Stegman EC, Schatz BG, Gardner JC (1990) Yield sensitivities of short season soybeans to irrigation management. Irrig Sci 11:111-119

7. Steduto P, Hsiao TC, Fereres E, Raes D (2012) Crop yield response to water, FAO Irrigation and Drainage Paper No, 66, pp 124-131

8. Bustomi Rosadi RA, Afandi, Senge M, Ito K, Adomako J (2007) The effect of water stress in regulated deficit irrigation on soybean yield (Glycine max [L.] Merr.). Paddy Water Environ 5:163-169

9. Momen NN, Carlson RE, Shaw RH, Arjmand O (1979) Moisture-stress effects on the yield components of two soybean cultivars. Agron J 71:86-90

10. Brevedan RE, Egli DB (2003) Short periods of water stress during seed filling, leaf senescence, and yield of soybean. Crop Sci 43:2083-2088

11. Korte LL, Williams JH, Specht JE, Sorensen RC (1983) Irrigation of soybean genotypes during reproductive ontogeny. I. Agronomic responses. Crop Sci 23(52):1-527

12. Huck MG, Peterson CM, Hoogenboom G, Bush CD (1986) Distribution of dry matter between shoots and roots of irrigated and non-irrigated soybeans. Agron J 78:807-813

13. Karam F, Masaad R, Sfeir T, Mounzer O, Rouphael Y (2005) Evapotranspiration and seed yield of field grown soybean under deficit irrigation conditions. Agric Water Manage 75:226-244

14. Torrion JA, Setiyono TD, Graef GL, Cassman KG, Irmak S, Specht JE (2014) Soybean irrigation management: Agronomic impacts of deferred, deficit, and full-season strategies. Crop Sci 54:2782-2795

15. Sincik M, Candogan BN, Demirtas C, Büyükcangaz H, Yazgan S, Göksoy AT (2008) Deficit irrigation of soyabean [Glycine max (L.) Merr.] in a sub-humid climate. J Agron Crop Sci 194:200-205

16. Garcia y Garcia A, Persson T, Guerra LC, Hoogenboom G (2010) Response of soybean genotypes to different irrigation regimes in a humid region of the southeastern USA. Agric. Water Manage. 97:981-987

17. Gercek S Boydak E, Okant M, Dikilitas M (2009) Water pillow irrigation compared to furrow irrigation for soybean production in a semi-arid area. Agric Water Manage 96:87-92

18. Allen RG, Pereira LS, Raes D, Smith M (1998) Crop Evapotranspiration: Guidelines for computing crop water requirements, FAO Irrigation and Drainage Paper No. 56, Food and Agriculture Organization (FAO). Land and Water Development Division, Rome, p 326

19. Siahpoosh MR, Dehghanian E (2012) Water use efficiency, transpiration efficiency, and uptake efficiency of wheat during drought. Agron J 104:1238-1243

20. Ali MH (2010) Fundamentals of irrigation and on-farm water management, vol 1. Springer Science, New York, p 578

21. Cooper PJM, Keatinge JDH, Hughes G (1983) Crop evapotranspiration-a technique for calculation of its components by field measurements. Field Crops Res 7:299-312

22. Lu X, Jin M, van Genuchten MT, Wang B (2011) Groundwater recharge at five representative sites in the Hebei Plain China. Groundwater 49:286-294

23. Araya A, Habtu S, Hadgu KM, Kebede A, Dejene T (2010) Test of AquaCrop model in simulating biomass and yield of water deficient and irrigated barley (Hordeum vulgare). Agric Water Manage 97:1838-1846

24. Lovelli S, Perniola M, Ferrara A, Di Tommaso T (2007) Yield response factor to water $\left(\mathrm{K}_{\mathrm{y}}\right)$ and water use efficiency of Carthamus tinctorius $\mathrm{L}$. and Solanum melongena L. Agric Water Manage 92:73-80

25. Zhang H, Owie T (1999) Water-yield relations and optima irrigation scheduling of wheat in the Mediterranean region. Agric Water Manage 38:195-211

26. Igbadun HE, Mahoo HF, Tarimo AKPR, Salim BA (2006) Crop water productivity of an irrigated maize crop in Mkoji sub-catchment of the Great Ruaha River Basin Tanzania. Agric Water Manage 85:141-150 
27. Food and Agricultural Organization of the United Nations (FAO): FAO food price index, at http://www.fao.org/worldfoodsituation/foodpricesindex/ en/2014. Accessed 20th Jun 2014

28. Egli DB (2005) Flowering, pod set and reproductive success in soya bean. J Agron Crop Sci 191:283-291

29. Nielsen DC (1990) Scheduling irrigations for soybeans with the Crop Water Stress Index (CWSI). Field Crops Res. 23:103-116

30. Doorenbos J, Kassam AH (1979) Yield response to water: FAO Irrigation and Drainage Paper No. 33, Rome, p 193

31. De Costa WAJM, Shanmugathasan KN (2002) Physiology of yield determination of soybean (Glycine max (L.) Merr.) under different irrigation regimes in the sub-humid zone of Sri Lanka. Field Crops Res 75:23-35

32. Dogan E, Kirnak H, Copur O (2007) Effect of seasonal water stress on soybean and site specific evaluation of CROPGRO-Soybean model under semi-arid climatic conditions. Agric Water Manage 90:56-62

33. Candogan BN, Sincik M, Buyukcangaz H, Demirtas C, Goksoy AT, Yazgan S (2013) Yield, quality and crop water stress index relationships for deficit-irrigated Soybean [Glycine max (L.) Merr.] in sub-humid climatic conditions. Agric Water Manage 118:113-121

34. Lamm FR, Abou Kheira AA, Trooien TP (2010) Sunflower, soybean and grain sorghum crop production as affected by drip line depth, Am Soc Agri Biol Eng 26:873-882, ISSN 0883-8542
35. Liu S, Zhang XY, Yang J, Drury CF (2013) Effect of conservation and conventional tillage on soil water storage, water use efficiency and productivity of corn and soybean in Northeast China. Acta Agriculturae Scandinavica Section B-Soil Plant Sci 63:383-394

36. Howell TA, Cuenca RH, Solomon KH (1990.) Crop yield response. In: Hoffman GJ et al (eds.), Management of Farm Irrigation Systems. Am. Soc. Agric. Eng (ASAE) St. Joseph, MI, pp 93-122

37. Neyshabouri MR, Hatfield JL (1986) Soil water deficit effects on semideterminate and indeterminate soybean growth and yield. Field Crops Res 15:73-84

38. Westgate ME, Whitgham K, Purcell L (2004) Soybean. In: Wringley C (ed) Encyclopaedia of grain science 2004, Elsevier, New York, pp 146-155

39. Oweis T, Hachum A (2006) Water harvesting and supplemental irrigation for improved water productivity of dry farming systems in West Asia and North Africa. Agric Water Manage 80:57-73

40. Geerts S, Raes D (2009) Deficit irrigation as an on-farm strategy to maximize crop water productivity in dry areas. Agric Water Manage 96:1275-1284

\section{Submit your next manuscript to BioMed Central and take full advantage of:}

- Convenient online submission

- Thorough peer review

- No space constraints or color figure charges

- Immediate publication on acceptance

- Inclusion in PubMed, CAS, Scopus and Google Scholar

- Research which is freely available for redistribution

Submit your manuscript at 